\title{
ZUZANNA NARKUN
}

The Maria Grzegorzewska University, Warsaw

\section{The teachers' self-efficacy and its importance for inclusive education}

AbSTRACT: Zuzanna Narkun, The teachers' self-efficacy and its im-portance for inclusive education. Interdisciplinary Contexts of Special Pedagogy, no. 25, Poznań 2019. Pp. 151-176. Adam Mickiewicz University Press. ISSN 2300-391X. DOI: https:// doi.org/10.14746/ikps.2019.25.07

The aim of this article was to describe the teachers' self-efficacy, self-efficacy for the purpose of inclusive practices, and to show its importance for the development of inclusion. Issues related to the self-efficacy of teachers (the definitions, the sources of self-efficacy, and the measurement of teachers' self-efficacy) have been described. The resulting findings of the research on teachers' self-efficacy, its antecedents and consequences have been presented. Moreover, connections between self-efficacy and effective implementation of inclusion have been discussed.

KEY WORDS: self-efficacy, inclusive education, teacher, students with special educational needs

\section{Introduction}

The teachers' self-efficacy, has been an issue examined by scholars since the 1970s. At that time, Albert Bandura, the founder of the social and cognitive theory, characterised the construct of the self-efficacy, and described it in the article titled Self-efficacy: Toward 
a Unifying Theory of Behavioral Change ${ }^{1}$. During a similar period, the American non-profit organisation called Research And Development (RAND), dedicated to conducting scientific research, i.a. within the area of education, drawing from the works of Julian Rotter, supplemented their questionnaire for teacher, with two sentences regarding the self-efficacy. The teacher's self-efficacy, is his belief regarding to what degree he is able to affect the behaviour and the school achievements of students, including those displaying various difficulties ${ }^{2}$. In the course of a several dozen years of research regarding the teachers' self efficacy, it was demonstrated, that it remains in correlation with numerous variables, such as vocational stress, or satisfaction drawn from work ${ }^{3}$. The teachers that display stronger self-efficacy, are more involved in the process of teaching, and, as a result, their students achieve better scholarly results 4 .

The analyses of the self-efficacy of the Polish teachers, are scarce $^{5}$. The self-efficacy of the teachers within inclusive education, which is an increasingly discussed issue among foreign scholars ${ }^{6}$, is

${ }^{1}$ A. Bandura, Self-efficacy: Toward a Unifying Theory of Behavioral Change, "Psychological Review" 1977, 84, pp. 191-215.

2 A.I. Friedman, E. Kass, Teacher Self-efficacy: a classroom-organization conceptualization, "Teaching and Teacher Education" 2002, 18, pp. 675-686.

${ }^{3}$ G.V. Caprara, C. Barbaranelli, L. Borgogni, P. Steca, Efficacy beliefs as determinants of teachers' job satisfaction, "Journal of Educational Psychology" 2003, 95, pp. 821-832; E.M. Skaalvik, S. Skaalvik, Teacher self-efficacy and teacher burnout: A study of relations, "Teacher and Teacher Education" 2010, 26, pp. 1059-1069.

${ }^{4}$ C.K. Herman, J. Rosa-Hickmon, M. W. Reinke, Empirically Derived Profiles of Teacher Stress, Burnout, Self-Efficacy and Coping Associated Student Outcomes, "Journal of Positive Behavior Interventions" 2018, 20, pp. 90-100.

${ }^{5}$ Ł. Baka, Skala poczucia własnej skuteczności nauczycieli-psychometryczne właściwości polskiej wersji narzędzia, "Medycyna Pracy” 2017, 6, pp. 743-754; M. Chomczyńska-Rubacha, K. Rubacha, Test poczucia skuteczności. Podręcznik pracowni narzędzi badawczych Komitetu Nauk Pedagogicznych PAN, Wydawnictwo Naukowe UMK, Toruń 2016; E. Kulawska, Poczucie własnej skuteczności nauczycieli edukacji wczesnoszkolne, „Forum Pedagogiczne” 2017, 2, pp. 237-251.

${ }^{6}$ O.P. Malinen, H. Savolainen, J. Xu, Beijing in-service teachers' self-efficacy and attitudes towards inclusive education, "Teaching and Teacher Education" 2012, 28, pp. 526-534; H. Savolainen, P. Engelbrecht, M. Nel, O.P. Malinen, Understanding 
absent within Polish research. The following article aims at characterising the self-efficacy of the teachers, and explaining, why it is of such importance for the effective implementation of inclusive education in educational practice. Next, we shall discuss the determinants of a teacher's self-efficacy within inclusive education, as well as, its consequence for the effects of education, i.e. the scholarly achievements of the students.

\section{The self-efficacy}

The self-efficacy may be understood as a belief of a person, regarding their capability of performing a particular task ${ }^{7}$. The belief, in a sense of a cognitive process, is the basis of taking action, including that, the circumstances of which are unknown, or considered as stressful to the individual 8 .

By presenting the social and cognitive theory of personality, the understanding of the construct of the self-efficacy will be more profound, as this is the original source of the term. The social and cognitive theory of personality (previously defined as the social learning theory), with its leading representative Albert Bandura, assumes, that man acquires skills by means of modelling, i.e. observation of other people ${ }^{9}$. Observational learning may occur due to four constitutive processes: attention, retention, motor initiation,

teachers' attitudes and self-efficacy in inclusive education: implications for pre-service and in-service teacher education, "European Journal of Special Needs Education" 2012, 27, pp. 51-68; A. Yada, H. Savolainen, H., Japanese in-service teachers' attitudes towards inclusive education and self-efficacy for inclusive practices, "Teaching and Teacher Education" 2017, 64, pp. 222-229.

7 A. Bandura, Teoria społecznego uczenia się, Wydawnictwo Naukowe PWN, Warszawa 2015.

8 J. Strelau, D. Doliński (red.), Psychologia. Podręcznik akademicki, Gdańskie Wydawnictwo Psychologiczne, Gdańsk 2008, Volume 1, pp. 712-716.

${ }^{9}$ L.A. Pervin, O.P. John, Osobowość. Teoria i badania, Wydawnictwo UJ, Kraków 2001, pp. 467-527. 
and motivation ${ }^{10}$. The observation of a given behaviour may be initiated, only if a person turns its attention to it. The process does not take into account solely the quality of the observed situation (e.g. its clarity, or incidence), but also the features of the observer himself (his abilities, his attitude). An individual would be unable to recreate a given activity, if not for the initiation of the processes of memorising, which allow the retention, in memory, of the patterns of behaviour in an imaginary or verbal manner. Apart from creating symbolic representations, exercise and repetition of the given actions are also of importance, allowing to perpetuate the aforementioned. Another factor, being a component of modelling, is the motor initiation, i.e. the process of transferring the remembered pattern into an actual action. Apart for the previously shaped symbolic representations, for the final model of behaviour to take shape, the individual requires corrective activities, acquired by means of self-observation, or coming from external factors (feedback). However, a person will not initiate an observed action, if deprived of sufficient motivation. Moreover, the person will be more eager to realise types of behaviour, that will yield particular benefits ${ }^{11}$.

The key premise of the social and cognitive theory is the analysis of the behaviour through the viewpoint of reciprocal determinism. Reciprocal determinism assumes, that the actions of people should be examined, while considering a number of factors that affect each other mutually, i.e. cognitive, environmental, and those related to the behaviour itself. Each of these determinants affects the others in some way. Therefore, Bandura discarded the previous theories, that treated behaviour solely as a result of the interaction between the personal features of a person, and the situation, in which the person found himself/herself. It is worth noting, that the cognitive factors within the reciprocal determinism theory, are taken

10 A. Bandura, Teoria społecznego uczenia się, Wydawnictwo Naukowe PWN, Warszawa 2015.

11 A. Bandura, Teoria spotecznego uczenia się, Wydawnictwo Naukowe PWN, Warszawa 2015. 
dynamically and encompass the human personality, i.e. the structure of his "I" , and the expectations regarding own efficacy ${ }^{12}$.

Bandura clearly differentiated between the expectations regarding efficacy, from the expectations regarding the result of a given behaviour, positive or negative, estimated by the individual ${ }^{13}$. The division has become a subject of critique. It is claimed, that the expectations regarding a result are essential for initiating a particular action. Moreover, if a person believes, that they can accomplish a certain action, then surely they must expect a positive result ${ }^{14}$. Bandura tackled these arguments, demonstrating, that often, certain factors that influence the accomplishment of a task, remain partially or entirely beyond the control of an individual. The behaviour of a given person will be estimated better, by the judgements regarding own efficacy, rather than the expectations of a result of behaviour. However, they are not equivalent to initiating action - if a person is assured of its negative result, despite the high self-efficacy, the action will not be taken ${ }^{15}$.

The self-efficacy affects such aspects of human functioning as emotions, thinking, and acting ${ }^{16}$. Additionally, one may state, that the self-efficacy does not remain without any influence regarding the motivational sphere of an individual. A person with a higher self-efficacy is more mobilised to take action, and puts more effort into it, in comparison with a person of a low self-efficacy. The individuals characterised by lower self-efficacy will be inclined to a lesser

${ }^{12}$ S.C. Hall, G. Lindzey, J.B. Campbell, Teorie osobowości, Wydawnictwo Naukowe PWN, Warszawa 2008, pp. 572-607.

${ }^{13}$ A. Bandura, Teoria społecznego uczenia się, Wydawnictwo Naukowe PWN, Warszawa 2015.

${ }^{14}$ L.A. Pervin, O.P. John, Osobowość. Teoria i badania, Wydawnictwo UJ, Kraków 2001, pp. 467-527.

${ }^{15}$ P.K. Oleś, Wprowadzenie do psychologii osobowości, Wydawnictwo Naukowe „Scholar", Warszawa 2003, pp. 210-216; L.A. Pervin, O.P. John, Osobowość. Teoria i badania, Wydawnictwo UJ, Kraków 2001, pp. 467-527.

${ }^{16}$ L.A. Pervin, O.P. John, Osobowość. Teoria i badania, Wydawnictwo UJ, Kraków 2001, pp. 467-527. 
involvement in the actions undertaken, much earlier frustration with failures, as well as, displaying higher degrees of fear and stress. Based on the judgements regarding self-efficacy, a person establishes aims, that they are willing to achieve. One may assume, that a person with a high self-efficacy may choose more ambitious aims, than a person with a low self-efficacy ${ }^{17}$.

As self-efficacy is not a general feature, natural to man, but various, depending on the area of the human functioning, one may speak of a teachers' self-efficacy.

\section{The teachers' self-efficacy}

There are two types of approach in the understanding of the self-efficacy: the RAND organisation approach, based on the works of Julian Rotter, and Bandura's approach. Within the first approach regarding the self-efficacy of teachers, self efficacy is perceived as a two-dimensional construct, which includes a general, and a personal self-efficacy. The general self-efficacy of the teacher refers to his beliefs regarding to what degree, generally, the teachers are capable of influencing students, considering the factor that are beyond their, and the school's control (e.g. the house environment of the student). However, personal self-efficacy consists of the teacher's beliefs regarding his own capabilities of affecting the process of learning ${ }^{18}$. Bandura considers the self-efficacy, as a certain subtype of the self-efficacy ${ }^{19}$. The definition by Thomas Guskey and Perry Passaro, fits the approach, started by Bandura, well, as they defined the teacher's self efficacy, as a belief regarding how much he can

17 P.K. Oleś, Wprowadzenie do psychologii osobowości, Wydawnictwo Naukowe „Scholar", Warszawa 2003, pp. 210-216; L.A. Pervin, O.P. John, Osobowość. Teoria i badania, Wydawnictwo UJ, Kraków 2001, pp. 467-527.

$18 \mathrm{~J}$.A. Ross, The impact of an in-service to promote cooperative learning on the stability of teacher efficacy, "Teaching and Teacher Education" 1994, 10, pp. 381-394.

19 A. Bandura, Self-efficacy: Toward a Unifying Theory of Behavioral Change, "Psychological Review"1977, 84, pp. 191-215. 
influence the school achievements of a student, even the student who is demotivated, or displays certain difficulties in the educational process ${ }^{20}$.

The self-efficacy is considered to be a multi-dimensional construct that encompasses such aspects of efficacy as: classroom management efficacy, teaching efficacy, efficacy in motivating and encouraging students, efficacy in cooperating with other specialists and parents ${ }^{21}$.

Bandura saw the sources of the self-efficacy in four factors, i.e. mastery experiences, vicarious experiences, verbal persuasion, and emotional/physiological states ${ }^{22}$. These factors, in reference to the person of a teacher, are presented in table no. 1 .

Table 1. The sources of teacher's self-efficacy

\begin{tabular}{|l|l|}
\hline \multicolumn{1}{|c|}{ The sources of self-efficacy } & \multicolumn{1}{c|}{ Characteristics } \\
\hline Mastery Experiences & $\begin{array}{l}\text { The successes and failures of the person } \\
\text { as a teacher, his professional experience. } \\
\text { It is especially important in regard to } \\
\text { teachers with long experience. }\end{array}$ \\
\hline Vicarious Experiences & $\begin{array}{l}\text { Observing other teachers during work, } \\
\text { e.g. inspections, student practices. }\end{array}$ \\
\hline Verbal Persuasion & $\begin{array}{l}\text { Information regarding the teacher's } \\
\text { abilities, provided by other persons, e.g. } \\
\text { "You will be a great teacher. You know } \\
\text { how to maintain the group". }\end{array}$ \\
\hline Emotional/Physiological States & $\begin{array}{l}\text { The observation of the organism's reac- } \\
\text { tion, in stressful situations. }\end{array}$ \\
\hline
\end{tabular}

Source: own research.

${ }^{20}$ T.R. Guskey, P.D. Passaro, Teacher efficacy: A study of construct dimensions, “American Educational Research Journal" 1994, 31, pp. 627-643.

${ }^{21}$ O.P. Malinen, H. Savolainen, J. Xu, J, Beijing in-service teachers' self-efficacy and attitudes towards inclusive education, "Teaching and Teacher Education" 2012, 28, pp. 526-534.

22 A. Bandura, Teoria społecznego uczenia się, Wydawnictwo Naukowe PWN, Warszawa 2015. 
The most important factor for the forming of self-efficacy are the mastery experiences, that refer to the personal experiences within an area of a particular action. However, the correlation may be referred to the pedagogues with long experience. In terms of younger teachers, who do not possess significant experience in professional practice, the remaining factors will play a much more important role, i.e. vicarious experiences, acquired via inspections, or student practices, as well as, verbal persuasion as information coming from other sources, e.g. the school principal ${ }^{23}$. Therefore, it is constantly important, to provide the candidates for the teaching profession, as well as, young teachers, as many models worth imitating, as possible, e.g. by allowing them to realise work practice in establishments with highly qualified staff. Comparative research conducted in Japan and Finland, regarding the teachers' self efficacy in inclusive education, and its sources, show, that it is the mastery experiences that are its strongest predictor ${ }^{24}$. It was also noticed, that the influence level of the remaining sources, varied in both countries. Verbal persuasion correlated negatively with the self-efficacy of the Japanese teachers, and the emotional/physical states were much more significant for the efficacy of the Finnish pedagogues. The aforementioned demonstrates, that analysing self-efficacy and its sources, one must consider the cultural context. The expectation of own efficacy, emphasising on the personal beliefs of a person regarding the beliefs about their capabilities in accomplishing a task, is closely tied to individualistic cultures, where the independence of an individual is highlighted. However, Bandura thought, that self-efficacy is equally important in collectivist cultures, as even there, a person

${ }^{23}$ M. Tschannen-Moran, A.Woolfolk Hoy, The differential antecedents of selfefficacy beliefs of novice and experienced teachers, "Teaching and Teacher Education" 2007, 23, pp. 944-956.

24 A. Yada, A. Tolvanen, O.P. Malinen, K. Imai-Matsumura, H. Shimada, R. Koike, H. Savolainen, Teachers' self-efficacy and the sources of efficacy: A cross-cultural investigation in Japan and Finland, "Teacher and Teacher Education" 2019, 81, pp. 13-24. 
doesn't lose their personal beliefs ${ }^{25}$. Klassen ${ }^{26}$, while conducting an overview of self-efficacy among people in various countries, notes that the persons from individualistic cultures evaluate their selfefficacy higher than the persons from collectivist cultures. What is interesting, is that the persons from collectivist cultures, despite evaluating their self-efficacy lower, they do it more adequately to their actually possessed capabilities. Fulgini 27 , while conducting research about the education of the children of immigrants, demonstrated that Americans of Japanese descent have evaluated their self-efficacy lower than Americans of European descent, however, they were the ones who were more successful in school evaluation.

It was demonstrated, that the self-efficacy of a teacher, during the first year of his work, is unstable and subject to manipulation. The research conducted by Woolfolk Hoy and Burke Spero 28 , demonstrated directly the increase in self-efficacy of the respondents during the pedagogical studies, and its decrease following the first year of work as a teacher. The scholars explain the phenomenon somewhat as a "clash with reality". The initial optimism decreases, when it comes to face the actual role and the tasks that come with it.

A teacher's self-efficacy works like feedback. A teacher with a high self-efficacy will be more involved in the process of teaching students, therefore, he will be more effective. The student's successes, in turn, will contribute to the level of the teacher's self-efficacy, but also the student's ${ }^{29}$. The interdependence highlights the im-

25 A. Bandura, Self-efficacy: Toward a Unifying Theory of Behavioral Change, "Psychological Review" 1977, 84, pp. 191-215.

${ }^{26}$ R.M. Klassen, Optimism and realism: A review of self-efficacy from a cross-cultural perspective, "International Journal of Psychology" 2004, 39, pp. 205-230.

27 A.J. Fulgini, The academic achievement of adolescents from immigrant families: The roles of family background, attitudes, and behavior, "Child Development" 1997, 68, pp. 351-363.

${ }^{28}$ A. Woolfolk Hoy, R. Burke Spero, Changes in teacher efficacy during the early years of teaching: A comparison of four measures, "Teaching and Teacher Education" 2005, 21, pp. 343-356.

${ }^{29}$ M. Tschannen-Moran, A. Woolfolk Hoy, W.K. Hoy, Teacher efficacy: Its meaning and measure, "Review of Educational Research" 1998, 68, pp. 202-248. 
portance of the teacher's beliefs regarding his efficacy. Not only knowledge regarding methodology, and the theory of teaching, are the decisive factors that determine the work of the teacher, its effects. His belief in the efficacy of his teaching is also of significance. While the studies' curricula aim at equipping the future students with the appropriate knowledge regarding pedagogy, the support of self-efficacy, as an element of preparing them for the profession, seems to be an omitted area.

In recent years, in response to various trends regarding the education of persons with special educational needs, analyses are being conducted, regarding the self-efficacy of teachers within inclusive education ${ }^{30}$. The self-efficacy of a teacher in inclusive education, may be perceived as his belief, regarding his capabilities of teaching in an inclusive classroom, of being able to deal with difficult behaviour, and of the possibility of cooperation with other teachers, specialists, and parents. A teacher, who displays low self-efficacy within inclusive education, will be convinced, that he is unable to teach in a varied group of students, including persons with special educational needs, and various difficulties ${ }^{31}$. Additionally, one must pay attention the the previously mentioned differentiation between the expectations regarding efficacy, and the result of the action. A teacher may possess high self-efficacy regarding teaching students with disabilities, and at the same time, assume that the process of their education will be ineffective. The aforementioned comes from the fact, that a number of factors appear, that cannot be

${ }^{30}$ O.P. Malinen, H. Savolainen, J. Xu, Beijing in-service teachers' self-efficacy and attitudes towards inclusive education, "Teaching and Teacher Education" 2012, 28, pp. 526-534; H. Savolainen, P. Engelbrecht, M. Nel, O.P. Malinen, Understanding teachers' attitudes and self-efficacy in inclusive education: implications for pre-service and in-service teacher education, "European Journal of Special Needs Education" 2012, 27, pp. 51-68; A. Yada, H. Savolainen, Japanese in-service teachers' attitudes towards inclusive education and self-efficacy for inclusive practices, "Teaching and Teacher Education" 2017, 64, pp. 222-229.

${ }^{31}$ U. Sharma, T. Loreman, Ch. Forlin, Measuring teacher efficacy to implement inclusive practices, "Journal of Research in Special Educational Needs" 2011, 12, pp. 12-21. 
controlled entirely, e.g. access to specialist means, or the attitude of able-bodied students.

The next section of the text will contain approximate determinants and consequences of self-efficacy of teachers in inclusive educations. In a situation, where such analyses, stricte dedicated to the self-efficacy in inclusive education, have not yet been conducted, studies regarding the self-efficacy of teachers in general will be presented. Inquiries will be undertaken, regarding, how the results of this research can be referred to working in a diverse classroom.

\section{Self-efficacy of teachers in inclusive education: its determinants and consequences}

The teacher's self-efficacy remains in a relation with various variables, that play an important role in the process of teaching, as proven in numerous empirical studies, and theoretical analyses ${ }^{32}$. As already mentioned, one may also note and increasing number of studies regarding self-efficacy in inclusive education ${ }^{33}$.

The factors related to the self-efficacy of a teacher, can be divided into two groups. The first group refers to the variables related to the teacher himself, therefore, the determinants of his self-efficacy, both personal (i.a. the attitudes towards inclusive education, work experience, experience in working with students with disabilities), and supra-personal, mostly related to the preparation for working

32 R.M. Klassen, V.M.C. Tze, S.M. Betts, K.A. Gordon, Teacher efficacy research 1998-2009: Signs of Progress or unfulfilled promise?, "Educational Psychology Review" 2011, 23, pp. 21-43; M. Zee, Y.M.H. Koomen, Teacher Self-Efficacy and Its Effects on Classroom Processes, Student Academic Adjustment, and Teacher Well-Being: A Synthesis of 40 Years of Research, "Review of Educational Research" 2016, 86, pp. 981-1015.

33 C. Forlin, U. Sharma, T. Loreman, Predictors of improved teaching efficacy following basic training for inclusion in Hong Kong, "International Journal of Inclusive Education" 2014, 18, pp. 718-730; A. Yada, A. Tolvanen, H. Savolainen, Teachers' attitudes and self-efficacy on implementing inclusive education in Japan and Finland: A comparative study using multi-group structural equation modelling, "Teaching and Teacher Education" 2018, 75, pp. 343-355. 
with students with special educational needs. The other area, are the consequences of self-efficacy - the results of education, here, taken as students' school achievements.

Inclusive education is currently one of the priorities of the educational policies in the entire world ${ }^{34}$. Attitudes regarding the nonsegregated education of students is one of the key factors of implementing the idea of inclusion to the educational practice ${ }^{35}$. The Meijer and Foster ${ }^{36}$ research shows, that the teachers with high self-efficacy, more often than the teachers with low self-efficacy, think, that an ordinary classroom is an appropriate educational space for both children with, or without disabilities. The correlation was confirmed by Soodak and Podell 137 , in the analyses conducted among New York leading and special teachers, as well as, by Weisel and Dror ${ }^{38}$, on a control group of Israeli teachers. The analyses in this area were conducted also while stricte examining the self-efficacy of the teachers in the inclusive education. Savolainen et al. ${ }^{39}$ have demonstrated, that the teachers with a higher self-efficacy in inclusive education, are more inclined towards the non-segregated education of students with special educational needs. This correlation was confirmed by Malinen et al. ${ }^{40}$, as well as, Yada and Savo-

${ }^{34}$ M. Ainscow, M. César, Inclusive education ten years after Salamanca: Setting the Agenda, "European Journal of Psychology of Education" 2006, 21, pp. 231-238.

$35 \mathrm{~B}$. Norwich, The relationship between attitudes to the integration of children with special educational needs and wider socio-political views: a US-English comparison, "European Journal of Special Needs Education" 1994, 9, pp. 91-106.

36 C.J.W. Meijer, S.F. Foster, The effect of teacher self-efficacy on referral change, "Journal of Special Education" 1988, 22, pp. 378-385.

37 L.C. Soodak, D.M. Podell, Teacher efficacy and student problem as factors in special education referral, "Journal of Special Education" 1993, 27, pp. 66-81.

38 A. Weisel, O. Dror, School climate, sense of efficacy and Israeli teachers' attitudes toward inclusion of students with special Leeds, "Education, Citizenship and Social Justice" 2006, 1, pp. 157-174.

${ }^{39}$ H. Savolainen, P. Engelbrecht, M. Nel, O.P. Malinen, Understanding teachers' attitudes and self-efficacy in inclusive education: implications for pre-service and in-service teacher education, "European Journal of Special Needs Education" 2012, 27, pp. 51-68.

40 O. P. Malinen, H. Savolainen, J. Xu, J, Beijing in-service teachers' self-efficacy and attitudes towards inclusive education, "Teaching and Teacher Education" 2012, 28, pp. 526-534. 
lainen ${ }^{41}$, in their research. As was already highlighted, self efficacy affects human thinking, emotions, and action ${ }^{42}$. These areas, transfer respectively to the aspects of attitudes: cognitive, affective and behavioural ${ }^{43}$. Therefore, one may assume, that a teacher's high selfefficacy, implies his positive attitude to the common education of children with disabilities and without them, and not the other way around ${ }^{44}$.

The mastery experiences are the most important of factors that shape self-efficacy. However, one should remember, that not only master experience will form the high self-efficacy ${ }^{45}$. Teachers with longer experience are characterised by higher self efficacy in inclusive education ${ }^{46}$. However, this correlation is not always observed. The positive relation of the self-efficacy in inclusive education, and work experience, was revealed in a control group of Japanese and Chinese teachers, however, it was not observed among the teachers from Finland or South Africa ${ }^{47}$. It seems that these discrepancies

${ }^{41}$ A. Yada, H. Savolainen, H., Japanese in-service teachers' attitudes towards inclusive education and self-efficacy for inclusive practices, "Teaching and Teacher Education" 2017, 64, pp. 222-229.

${ }^{42}$ L. A. Pervin, O. P. John, Osobowość. Teoria i badania, Wydawnictwo UJ, Kraków 2001, pp. 467-527.

${ }^{43}$ B. Wojciszke, Człowiek wśród ludzi, Wydawnictwo Naukowe Scholar, Warszawa 2009, p. 181.

${ }^{44}$ O.P. Malinen, H. Savolainen, J. Xu, J, Beijing in-service teachers' self-efficacy and attitudes towards inclusive education "Teaching and Teacher Education" 2012, 28, pp. 526-534.

${ }^{45}$ A. Bandura, Teoria społecznego uczenia się, Wydawnictwo Naukowe PWN, Warszawa 2015.

${ }^{46}$ A. Yada, A. Tolvanen, H. Savolainen, Teachers' attitudes and self-efficacy on implementing inclusive education in Japan and Finland: A comparative study using multigroup structural equation modelling, "Teaching and Teacher Education" 2018, 75, pp. 343-355.

${ }^{47}$ O.P. Malinen, H. Savolainen, P. Engelbrecht, J. Xu, M. Nel, N. Nel, D. Tlale, Exploring teacher self-efficacy for inclusive practices in three diverse countries, "Teaching and Teacher Education" 2013, 33, pp. 34-44; A. Yada, A. Tolvanen, H. Savolainen, Teachers' attitudes and self-efficacy on implementing inclusive education in Japan and Finland: A comparative study using multi-group structural equation modelling, "Teaching and Teacher Education" 2018, 75, pp. 343-355. 
may be caused by cultural differences. In countries such as Japan or China, elders, people with more experience, are given more respect, and that may explain, why the self-efficacy increases accordingly to work experience ${ }^{48}$.

Such experiences of working with students with disabilities, positively affect the level of self-efficacy in inclusive education. The research conducted by Yada et al. ${ }^{49}$, demonstrated that the teachers, who declared higher experience in working with students with disabilities, at the same time, displayed a higher level of self-efficacy in inclusive education. The correlation is also confirmed by the research performed among teachers from Finland, China and South Africa, where the experiences of teaching children with disabilities, functioned as the most significant predictor of own self-efficacy in inclusive education ${ }^{50}$.

A variable, positively correlating with the teachers' self efficacy, is their preparation for working with students with special educational needs. Forlin and his associates ${ }^{51}$, demonstrated that, after completing a course on inclusive education, the self-efficacy of the teachers in inclusive education increased. Therefore, including the contents regarding the education of persons with disabilities in educational curricula of the future teachers, is necessary and important, not only of the obvious reason of equipping them with knowledge

${ }^{48}$ A. Yada, A. Tolvanen, H. Savolainen, Teachers' attitudes and self-efficacy on implementing inclusive education in Japan and Finland: A comparative study using multigroup structural equation modelling, "Teaching and Teacher Education" 2018, 75, pp. 343-355.

${ }^{49}$ A. Yada, A. Tolvanen, H. Savolainen, Teachers' attitudes and self-efficacy on implementing inclusive education in Japan and Finland: A comparative study using multigroup structural equation modelling, "Teaching and Teacher Education" 2018, 75, pp. 343-355.

${ }^{50}$ P. Malinen, H. Savolainen, P. Engelbrecht, J. Xu, M. Nel, N. Nel, D. Tlale, Exploring teacher self-efficacy for inclusive practices in three diverse countries, "Teaching and Teacher Education" 2013, 33, pp. 34-44.

${ }^{51}$ C. Forlin, U. Sharma, T. Loreman, Predictors of improved teaching efficacy following basic training for inclusion in Hong Kong, "International Journal of Inclusive Education" 2014, 18, pp. 718-730. 
on the subject matter. The information regarding inclusive education in academic curricula, may also aid the formation of a high self-efficacy of teachers working in inclusive classrooms.

The experienced stress, related to the work, that, when experienced in long-term, may lead to professional burnout, is one of the issues, which the teachers must tackle ${ }^{52}$. The negative relation between professional burnout, and self efficacy, is indicated by Brown ${ }^{53}$ in his overview article, and by the meta-analysis of Aloe and associates ${ }^{54}$. Schwarzer and Hallum ${ }^{55}$, demonstrated, that the teachers with lower self-efficacy are more prone to the experience of professional stress and, in consequence, to the professional burnout. The analyses conducted by Skaalvik and Skaalvik ${ }^{56}$, demonstrate that the selfefficacy remains in relation to the symptoms of a professional burnout: depersonalisation and emotional exhaustion. The analyses, using the method of structural equations, conducted on a group of 2249 Norwegian teachers, revealed that both the emotional exhaustion, as well as, depersonalisation, are negatively correlated with self-efficacy. Additionally, the study revealed, that the self-efficacy is positively correlated with the satisfaction drawn from work. The negative relation of the professional breakdown and self-efficacy is also indicated by the research presented by Evers, Brouwerse and Tomic ${ }^{57}$, conducted among Dutch teachers from secondary schools.

${ }^{52}$ H.K. Jennett, S.L. Harris, G.B. Mesibov, Commitment to philosophy, teacher efficacy, and burnout among teachers of children with autism, "Journal of Autism and Developmental Disorders" 2003, 33, pp. 583-593.

53 C.G. Brown, A systematic review of the relationship between self-efficacy and burnout in teachers, "Educational and Child Psychology" 2012, 29, pp. 47-63.

54 A.M. Aloe, L.C. Amo, M.E. Shanahan, Classroom management self-efficacy and burnout: A multivariate meta-analysis, "Educational Psychology Review" 2014, 26, pp. 101-126.

55 R. Schwarzer, S. Hallum, Perceived teacher self-efficacy as a predictor of job stress and burnout: Mediation analyses, "Applied Psychology" 2008, 57, pp. 152-171.

56 E.M. Skaalvik, S. Skaalvik, Teacher self-efficacy and teacher burnout: A study of relations, "Teacher and Teacher Education" 2010, 26, pp. 1059-1069.

57 A. Brouwers, W. Tomic, A longitudinal study of teacher burnout and perceived self-efficacy in classroom management, "Teacher and Teacher Education" 2002, 16, pp. 239-253. 
The positive correlation between satisfaction drawn from work and self-efficacy was demonstrated in the analyses conducted among Italian teachers, by Caprara and associates ${ }^{58}$. What is worth mentioning, Malinen and Savolainen ${ }^{59}$, in a longitudinal study of the teachers from Finland, demonstrated that the self efficacy, and being able to deal with difficult behaviour (one of the aspects of self-efficacy in inclusive education) was a predictor of both the professional burnout, as well as, satisfaction drawn from work.

Studies dedicated to the stress at work, and satisfaction drawn from work, were referring to the self-efficacy of the teacher in general, and not self-efficacy in inclusive education. However, a decision was made to include the results of these studies, as the analysed factors are essential, within the context of accomplishing inclusive practices. One may assume, that the stress associated with work in an inclusive classroom is higher than in a classroom without the student with special educational needs. This may constitute a high-risk factor regarding the professional burnout. Additionally, achieving high satisfaction, while working in an inclusive classroom, may prove difficult. Students with intellectual disabilities, or autism-spectrum disorders, due to their limitations, are often unable to meet certain requirements, which in turn may negatively affect the feeling of satisfaction for the teacher. Moreover, the OECD (Organisation for Economic Co-operation and Development) report demonstrates, that the teachers who have students with behavioural problems in their classroom, display a lower level of satisfaction drawn from work 60 .

58 G.V. Caprara, C. Barbaranelli, P. Steca, P.S. Malone, Teachers' self-efficacy beliefs as determinants of job satisfaction and students' academic achievement: A study at the school level, "Journal of School Psychology" 2006, 44, pp. 473-490; G.V. Caprara, C. Barbaranelli, L. Borgogni, P. Steca, Efficacy beliefs as determinants of teachers' job satisfaction, "Journal of Educational Psychology" 2003, 95, pp. 821-832.

59 O.P. Malinen, H. Savolainen, The effect of perceived school climate and teacher efficacy in behavior management on job satisfaction and burnout: A longitudinal study, "Teacher and Teacher Education" 2016, 60, pp. 144-152.

60 OECD, Talis 2013 results: An international perspective on teaching and learning, OECD Publishing, Paryż 2014. 
Considering the described relations between self-efficacy, stress, professional burnout, and work satisfaction, one may assume, that self-efficacy in inclusive education may be lower than self-efficacy of a teacher in general.

Allinder ${ }^{61}$ studied the self-efficacy of the teachers that work directly with students, and those that only served as consultants. The analyses demonstrated, that the teachers with a higher self-efficacy were open to new methods of teaching, involved in the process of education, as well as, just, and decisive in difficult situations. Additionally, it was demonstrated that the self-efficacy, affects the way he perceives his professional role, the way he teaches, and his relation with the students. These relations were observed in both studied groups. Although the research did not refer to self-efficacy in inclusive education, but self-efficacy of the teacher in general, that indicates a very important relation for the purpose realising inclusive practices. Working in a non-segregated classroom is an enormous challenge for the teacher. He must adjust his methods to varying needs, and capabilities of the students, as well as, the teacher more often faces difficult behaviour, and conflict situations in the classroom. As Allinder's study demonstrated, a high self-efficacy will allow the teacher to better deal with such situations.

A separate area of the research regarding the teachers' self-efficacy is the one related to the accomplishments of students. Unfortunately, there is yet to be an analysis on the relation of own self-efficacy in inclusive education to the results in the students' results in such classrooms. Thus, a decision was made to include the results of the studies regarding the self-efficacy of teachers in general. The conclusion coming from these studies, indicates the existence of a positive relation between the teacher's self-efficacy, and the students' accomplishments. In a study on the American, fifth-grade teachers,

61 R. M. Allinder, The relationship between efficacy and the instructional practices of special education teachers and consultants, "Teacher Education and Special Education 1994,17 , pp. $86-95$. 
Guo and associates ${ }^{62}$, demonstrated that the teachers with high selfefficacy, create a more friendly environment for learning, they are emphatic and supportive, and their students achieve better results in linguistic skills. Additionally, the analyses conducted by Ross ${ }^{63}$, on history teachers, indicate a positive relation between the teacher's high self efficacy, and the students' achievements. A study conducted by Herman et al.64, aimed at creating profiles of teachers, due to their stress levels, their ability to handle themselves, their professional burnout, and their self-efficacy. Additionally, relations between individual types of teachers, and the school achievements of their students, taken as scholarly results, and behaviour, were analysed. The analyses showed, that the students, whose teachers displayed lower self-efficacy, and handling themselves, along with a high degree of stress, also displayed lower results in education, and worse behaviour. What is interesting, the majority of the studied teachers (93\%) declare a high level of professional stress experienced.

In the aforementioned, longitudinal studies conducted by Caprara and associates ${ }^{65}$, apart from the relation between selfefficacy and the satisfaction drawn from work, the results of students, who finished the phase of compulsory education, were also examined. Although it was demonstrated, that the teacher's self efficacy is a predictor of the student's results, a different, interesting correlation was shown. It was demonstrated, that the earlier achieve-

${ }^{62}$ Y. Guo, C. McDonald Connor, Y. Yang, A.D. Roehring, F.J. Morrison, The effects of teacher qualification, teacher self-efficacy, and classroom practices on fifth graders' literacy outcomes, "Elementary School Journal" 2012, 113, pp. 3-24.

${ }^{63} \mathrm{~J}$. A. Ross, Teacher efficacy and the effect of coaching on student achievement, "Canadian Journal of Education" 1992, 17, pp. 51-65.

${ }^{64}$ C.K. Herman, J. Rosa-Hickmon, M.W. Reinke, Empirically Derived Profiles of Teacher Stress, Burnout, Self-Efficacy and Coping Associated Student Outcomes, "Journal of Positive Behavior Interventions" 2018, 20, pp. 90-100.

${ }^{65}$ G.V. Caprara, C. Barbaranelli, P. Steca, P.S. Malone, Teachers' self-efficacy beliefs as determinants of job satisfaction and students' academic achievement: A study at the school level, "Journal of School Psychology" 2006, 44, pp. 473-490. 
ments of the students, had an influence on the later self-efficacy of the teachers. The result confirms the premises made by Bandura66, who highlighted, that the mastery experience is the most important factor for forming self-efficacy. Additionally, the study serves as a great example, that confirms the actions of self-efficacy of teachers, based on the feedback principle.

The definitions of teachers' self-efficacy highlight, that it also refers to the influence on the behaviour and scholarly results of those students, who display various kinds of difficulties, or low motivation $^{67}$. A teacher that works in a non-segregated classroom, most definitely encounters such students. Therefore, it seems that the study results, as described above, may translate to an inclusive classroom. On the other hand, thinking of self-efficacy in inclusive education, and its level, one may assume, that it will be lower than the self-efficacy of a teacher in general. Students with special educational needs may cause the teacher to have a more difficult time experiencing the success of his work, and success, as is known, is imperative for forming high self-efficacy.

The study results shown below, as well as others that fit the inquiries, are presented in table no. 2 .

Table 2. Teachers' self-efficacy: its determinants and consequences.

\begin{tabular}{|l|l|l|}
\hline \multicolumn{1}{|c|}{ Variable } & \multicolumn{1}{|c|}{ Example studies } & \multicolumn{1}{|c|}{ Primary conclusion } \\
\hline \multicolumn{2}{|c|}{ The determinants of the teachers' self-efficacy } \\
\hline $\begin{array}{l}\text { Attitudes towards a non- } \\
\text { segregated education of } \\
\text { students with special } \\
\text { educational needs }\end{array}$ & $\begin{array}{l}\text { Malinen et al. 2012; Meijer, } \\
\text { Foster, 1988; Savolainen et al., } \\
\text { 2012; Soodak, Podell, 1993; } \\
\text { Weisel, Dror, 2006 }\end{array}$ & $\begin{array}{l}\text { Teachers with higher self-efficacy } \\
\text { are more inclined towards inclu- } \\
\text { sive education. }\end{array}$ \\
\hline $\begin{array}{l}\text { Work experience } \\
\text { Malinen et al., 2013; Yada, Tol- } \\
\text { vanen, Savolainen, 2018 }\end{array}$ & $\begin{array}{l}\text { Teachers with more experience } \\
\text { declare higher self-efficacy. }\end{array}$ \\
\hline
\end{tabular}

66 A. Bandura, Self-efficacy: Toward a Unifying Theory of Behavioral Change, "Psychological Review" 1977, 84, pp. 191-215.

67 T. R. Guskey, P. D. Passaro, Teacher efficacy: A study of construct dimensions, "American Educational Research Journal" 1994, 31, pp. 627-643. 


\begin{tabular}{|l|l|l|}
\hline \multicolumn{1}{|c|}{ Variable } & \multicolumn{1}{|c|}{ Example studies } & \multicolumn{1}{c|}{ Primary conclusion } \\
\hline \multicolumn{2}{|c|}{ The determinants of the teachers' self-efficacy } \\
\hline $\begin{array}{l}\text { Experience in working } \\
\text { with students with disa- } \\
\text { bilities }\end{array}$ & $\begin{array}{l}\text { Malinen et al., 2013; Yada, Tol- } \\
\text { vanen, Savolainen, 2018 }\end{array}$ & $\begin{array}{l}\text { Experience in working with stu- } \\
\text { dents with disabilities is positive- } \\
\text { ly correlated with the teacher's } \\
\text { self-efficacy. }\end{array}$ \\
\hline $\begin{array}{l}\text { Preparation to work with } \\
\text { students with disabilities }\end{array}$ & Forlin, Sharma, Loreman, 2014 & $\begin{array}{l}\text { Being prepared in terms of spe- } \\
\text { cial pedagogy is positively corre- } \\
\text { lated with self-efficacy. }\end{array}$ \\
\hline $\begin{array}{l}\text { Application of innova- } \\
\text { tive educational methods }\end{array}$ & Allinder, 1994 & $\begin{array}{l}\text { Teachers with higher self-efficacy } \\
\text { are more eager to apply innova- } \\
\text { tive educational methods. }\end{array}$ \\
\hline Professional stress & $\begin{array}{l}\text { Herman et al., 2018; Schwarzer, } \\
\text { Hallum, 2008 }\end{array}$ & $\begin{array}{l}\text { Teachers with lower self-efficacy } \\
\text { are more prone to experience } \\
\text { work stress. }\end{array}$ \\
\hline Professional burnout & $\begin{array}{l}\text { Brouwers, Tomic, 2000 Evers, } \\
\text { Brouwers, Tomic, 2002; } \\
\text { Schwarzer, Hallum, 2008; } \\
\text { Skaalvik, Skaalvik, 2007, 2010 }\end{array}$ & $\begin{array}{l}\text { Teachers with higher self-efficacy } \\
\text { are less prone to professional } \\
\text { burnout. }\end{array}$ \\
\hline $\begin{array}{l}\text { Satisfaction drawn from } \\
\text { work }\end{array}$ & $\begin{array}{l}\text { Caprara et al., 2003, 2006; } \\
\text { Skaalvik, Skaalvik, 2010 }\end{array}$ & $\begin{array}{l}\text { Teachers with high self-efficacy } \\
\text { draw more satisfaction from work. }\end{array}$ \\
\hline \multicolumn{2}{|c|}{ The consequences of the teachers' self-efficacy - the educational results } \\
\hline $\begin{array}{l}\text { Students accomplish- } \\
\text { ments' }\end{array}$ & $\begin{array}{l}\text { Bandura, 1993; Caprara et al., } \\
\text { 2006; Gibson, Dembo, 1984; } \\
\text { Goddard, Hoy, Woolfolk, 2000; } \\
\text { Guo et al., 2012; Herman et al., } \\
\text { 2018; Midgley et al., 1988; Ross, } \\
\text { 1992; Skaalvik, Skaalvik, 2007 }\end{array}$ & $\begin{array}{l}\text { Students, whose teachers display } \\
\text { higher self-efficacy, achieve better } \\
\text { results in education. }\end{array}$ \\
\hline
\end{tabular}

Source: own research.

Analysing the available studies on the teachers' self-efficacy in inclusive education, it is also worth attempting to indicate the additional areas of further analyses regarding the phenomenon. The studies on the teacher's self-efficacy in inclusive education, and on the educational results, seem to be particularly important. The studies regarding the accomplishments of students in non-segregated (and segregated) forms, always arouse much interest, and their rela- 
tion with self-efficacy in inclusive education is, without a doubt, an interesting area of further analyses in the subject. The educational results are another important area of future studies, however, considered within the social functioning of the students. An analysis of the inclusive classroom environment would be worth conducting, as they are the place of social integration of students with special educational needs, and determine, whether the teacher with higher self-efficacy in inclusive education, is able to create a more friendly atmosphere in the classroom, and efficiently prevent any type of school bullying in the classroom. It seems, that the factors, tied to the person of the teacher himself, are well examined. However, we still lack longitudinal analyses, that would allow for determining the direction of the correlation between the teacher's self-efficacy in inclusive education, and the particular personality variables.

\section{Summary}

The departure from the segregated education of students with disabilities for the sake if including them in the mainstream of education, draws from the ideas of social normalisation and integration, as we can see in legal acts, effective in European countries, including Poland. The Convention on the Rights of the Persons with Disabilities, adopted by the UN in 2006, and ratified by the Polish government six years later, serves the purpose of guaranteeing this group of persons, the ability to receive education in an environment, where they develop by providing them with an "inclusive education system" 68 . On the other hand, as noted by Grzegorz Szumski ${ }^{69}$, one may observe a certain crisis in the implementation of the inclusive practices, with the examples being, i.a. a low quantitative increment of mainstream establishments that include students

${ }^{68}$ Konwencja o prawach osób niepełnosprawnych, Dz. U. RP z dn. 25 października 2012 r., poz. 1169.

${ }^{69}$ G. Szumski, Edukacja włączająca - niedokończony projekt, "Ruch Pedagogiczny" 2014, 4, pp. 127-139. 
with disabilities, or the lack of systemic reforms for integration. The rejection of the idea of inclusive education carries severe consequences for the persons with disabilities, limiting their access to the full participation in social life, for special pedagogy, by impeding its development, and finally, for the entire educational system, making it closed to diversity, and strengthening the social differences. Considering the above aspects, taking action for the promotion of inclusion, seems extremely important. No doubt, the effective realisation of the premises of inclusive education, also requires practitioners, that are properly trained, and favourable towards students with special educational needs. Not only special pedagogy knowledge, and the know-how regarding the methods of educating persons with special educational needs, is necessary, in order for the teachers to be able to effectively teach in inclusive classes. What is needed, is a belief that they can accomplish this task. This belief is selfefficacy in inclusive education. Teachers' self-efficacy is correlated with numerous variables, that are of significant importance for the success of the process of education. A direct relation, referring to the idea of inclusion, is the one, that indicates, that the teachers with higher self-efficacy are more favourable to non-segregated education of students with special educational needs. Moreover, a teacher with high self-efficacy is usually more eager to dedicate himself to his work, which affects the students' scholarly results, including the students displaying various kinds of difficulties. Therefore, in the educational curricula of the future teachers, apart from elements regarding special pedagogy, attention should be turned to building self-efficacy. It may be achieved by providing high quality models of implementing inclusive education, so that young pedagogues could acquire vicarious experience, allowing them to develop high efficacy in education, including inclusive education. However, one must highlight, that in order to develop high self-efficacy, much care should be placed on ensuring, that the teacher will be able to enjoy success at work. Therefore, the transformation of schools into inclusive establishments, and providing teachers with the proper support in their work with students with special educational needs, is of such importance. 


\section{Bibliography}

Ainscow M., César M., Inclusive education ten years after Salamanca: Setting the agenda, "European Journal of Psychology of Education" 2006, 21, pp. 231-238.

Allinder R. M., The relationship between efficacy and the instructional practices of special education teachers and consultants, "Teacher Education and Special Education" 1994, 17, pp. 86-95.

Aloe A.M., Amo L.C., Shanahan M.E., Classroom management self- efficacy and burnout: A multivariate meta-analysis, "Educational Psychology Review" 2014, 26, pp. 101-126.

Baka Ł., Skala poczucia własnej skuteczności nauczycieli-psychometryczne właściwości polskiej wersji narzędzia, „Medycyna Pracy” 2017, 6, pp. 743-754.

Bandura A., Self-efficacy: Toward a Unifying Theory of Behavioral Change, "Psychological Review" 1977, 84, pp. 191-215.

Bandura A., Teoria społecznego uczenia się, Wydawnictwo Naukowe PWN, Warszawa 2015.

Brouwers A., Tomic W., A longitudinal study of teacher burnout and perceived self-efficacy in classroom management, "Teacher and Teacher Education" 2000, 16, pp. 239-253.

Brown C.G., A systematic review of the relationship between self-efficacy and burnout in teachers, "Educational and Child Psychology" 2012, 29, pp. 47-63.

Caprara G.V., Barbaranelli C., Steca P., Malone P.S., Teachers' self-efficacy beliefs as determinants of job satisfaction and students' academic achievement: A study at the school level, "Journal of School Psychology" 2006, 44, pp. 473-490.

Caprara G.V., Barbaranelli C., Borgogni L., Steca P., Efficacy beliefs as determinants of teachers' job satisfaction, "Journal of Educational Psychology" 2003, 95, pp. 821-832.

Chomczyńska-Rubacha M., Rubacha K., Test poczucia skuteczności. Podręcznik pracowni narzędzi badawczych Komitetu Nauk Pedagogicznych PAN, Wydawnictwo Naukowe UMK, Torun 2013.

de Boer A., Pijl J.S., Minnaert A., Regular primary school teacher attitudes towards inclusive Education: a review of the literature, "International Journal of Inclusive Education" 2011, 15, pp. 331-353.

Evers G.J.W., Brouwers A., Tomic W., Burnout and self-efficacy: A study on teachers beliefs when implementing a innovative educational system in Netherlands, "British Journal of Educational Psychology" 2002, 72, pp. 227-243.

Forlin C., Sharma U., Loreman T., Predictors of improved teaching efficacy following basic training for inclusion in Hong Kong, "International Journal of Inclusive Education" 2014, 18, pp. 718-730.

Fulgini A.J., The academic achievement of adolescents from immigrant families: The roles of family background, attitudes, and behavior, "Child Development" 1997, 68, pp. 351-363. 
Friedman A.I., Kass E., Teacher Self-efficacy: a classroom-organization Conceptualization, “Teaching and Teacher Education" 2002, 18, pp. 675-686.

Geijsel F.P., Sleegers P.J.C., Stoel R.D., Krüger M.L., The effect of teacher psychological, school organizational and leadership factors on teachers' Professional learning in Dutch schools, "The Elementary School Journal" 2009, 109, pp. 406-427.

Gibson S., Dembo M., Teacher efficacy: A construct validation, “Journal of Educational Psychology" 1984, 76, pp. 569-582.

Goddard R.D., Hoy W.K., Woolfolk Hoy, A., Collective teacher efficacy: Its meaning, measure, and effect on student achievement, "American Educational Research Journal" 2000, 37, pp. 479-507.

Guo Y., McDonald Connor C., Yang, Y., Roehring A.D., Morrison F.J., The effects of teacher qualification, teacher self-efficacy, and classroom practices on fifth graders' literacy outcomes, “Elementary School Journal” 2012, 113, pp. 3-24.

Guskey T. R., Passaro P. D., Teacher efficacy: A study of construct dimensions, "American Educational Research Journal" 1994, 31, pp. 627-643.

Hall S. C., Lindzey G., Campbell J. B., Teorie osobowości, Wydawnictwo Naukowe PWN. Warszawa 2004, pp. 572-607.

Herman C.K, Rosa-Hickmon J., Reinke M.W., Empirically Derived Profiles of Teacher Stress, Burnout, Self-Efficacy and Coping Associated Student Outcomes, "Journal of Positive Behavior Interventions" 2018, 20, pp. 90-100.

Jennett H.K., Harris S.L., Mesibov G.B., Commitment to philosophy, teacher efficacy, and burnout among teachers of children with autism, "Journal of Autism and Developmental Disorders" 2003, 33, pp. 583-593.

Klassen, R.M., Optimism and realism: A review of self-efficacy from a cross-cultural perspective, "International Journal of Psychology" 2004, 39, pp. 205-230.

Klassen R.M., Tze V.M.C., Betts S.M., Gordon K.A., Teacher efficacy research 19982009: Signs of Progress or unfulfilled promise?, "Educational Psychology Review" 2011, 23, pp. 21-43.

Konwencja o prawach osób niepełnosprawnych, Dz.U. RP z dn. 25 października 2012 r., poz. 1169.

Kulawska E., Poczucie wtasnej skuteczności nauczycieli edukacji wczesnoszkolnej. „Forum Pedagogiczne" 2017, 2, pp. 237-251.

Malinen O.P., Savolainen H., The effect of perceived school climate and teacher efficacy in behavior management on job satisfaction and burnout: A longitudinal study. "Teacher and Teacher Education" 2016, 60, pp. 144-152.

Malinen O.P., Savolainen H., Xu J., Beijing in-service teachers' self-efficacy and attitudes towards inclusive education, "Teaching and Teacher Education" 2012, 28, pp. 526-534.

Malinen, O.P., Savolainen, H., Engelbrecht, P., Xu, J., Nel, M., Nel, N., Tlale, D., Exploring teacher self-efficacy for inclusive practices in three diverse countries, “Teaching and Teacher Education" 2013, 33, pp. 34-44. 
Meijer C.J.W., Foster S.F., The effect of teacher self-efficacy on referral change, "Journal of Special Education" 1988, 22, pp. 378-385.

Midgley C., Feldlaufer H., Eccles J., Change in teacher efficacy and student self- and taskrelated beliefs in mathematics during the transition to junior high school, "Journal of Educational Psychology" 1989, 81, pp. 247-258.

Norwich B., The relationship between attitudes to the integration of children with special educational needs and wider socio-political views: a US-English comparison, "European Journal of Special Needs Education" 1994, 9, pp. 91-106.

OECD, Talis 2013 results: An international perspective on teaching and learning, OECD Publishing, Paryż 2014.

Oleś P.K., Wprowadzenie do psychologii osobowości, Wydawnictwo Naukowe "Scholar", Warszawa 2003, pp. 210-216.

Pervin L.A., John O.P., Osobowość. Teoria i badania, Wydawnictwo UJ, Kraków 2001, pp. 467-527.

Ross J.A., Teacher efficacy and the effect of coaching on student achievement, "Canadian Journal of Education" 1992, 17, pp. 51-65.

Ross J.A., The impact of an in-service to promote cooperative learning on the stability of teacher efficacy, ",Teaching and Teacher Education" 1994, 10, pp. 381-394.

Savolainen H., Engelbrecht P., Nel M., Malinen O.P., Understanding teachers' attitudes and self-efficacy in inclusive education: implications for pre-service and in-service teacher education, "European Journal of Special Needs Education" 2011, 27, pp. 51-68.

Schwarzer R., Hallum S., Perceived teacher self-efficacy as a predictor of job stress and burnout: Mediation analyses, "Applied Psychology" 2008, 57, pp. 152-171.

Sharma U., Loreman T., Forlin Ch., Measuring teacher efficacy to implement inclusive practices, "Journal of Research in Special Educational Needs" 2001, 12, pp. 12-21.

Skaalvik E.M., Skaalvik S., Dimensions of teacher self-efficacy and relations with strain factors, perceived collective teacher efficacy and teacher burnout, "Journal of Educational Psychology" 2007, 99, pp. 611-625.

Skaalvik E.M., Skaalvik S., Teacher self-efficacy and teacher burnout: A study of Relations, “Teacher and Teacher Education" 2010, 26, pp. 1059-1069.

Soodak L.C., Podell D.M., Teacher efficacy and student problem as factors in special education referral, “Journal of Special Education” 1993, 27, pp. 66-81.

Strelau J., Doliński, D. (eds.), Psychologia. Podręcznik akademicki. Vol. 1, Gdańskie Wydawnictwo Psychologiczne, Gdańsk 2008, pp. 712-716.

Szumski G., Edukacja włączająca - niedokończony projekt, "Ruch Pedagogiczny” 2014, 4, pp. $127-139$.

Thoonen E.E.J., Sleegers P.J.C., Peetsma T.T.D., Oort F.J., Can teachers motivate students to learn? "Educational Studies" 2011, 37, pp. 345-360.

Tschannen-Moran M., Woolfolk Hoy A., The differential antecedents of self-efficacy beliefs of novice and experienced teachers, "Teaching and Teacher Education" 2007, 23, pp. 944-956. 
Tschannen-Moran M., Woolfolk Hoy A., Hoy W.K., Teacher efficacy: Its meaning and measure, "Review of Educational Research" 1998, 68, pp. 202-248.

Weisel A., Dror O., School climate, sense of efficacy and Israeli teachers' attitudes toward inclusion of students with special needs, "Education, Citizenship and Social Justice" 2006, 1, pp. 157-174.

Wojciszke B., Człowiek wśród ludzi, Wydawnictwo Naukowe Scholar, Warszawa 2008, pp. 181.

Woolfolk Hoy, A., Burke Spero, R., Changes in teacher efficacy during the early years of teaching: A comparison of four measures, "Teaching and Teacher Education" 2005, 21, pp. 343-356.

Yada A., Tolvanen, A., Savolainen H., Teachers' attitudes and self-efficacy on implementing inclusive education in Japan and Finland: A comparative study using multi-group structural equation modelling, "Teaching and Teacher Education" 2018, 75, pp. $343-355$.

Yada A., Savolainen H, Japanese in-service teachers' attitudes towards inclusive education and self-efficacy for inclusive practices, "Teaching and Teacher Education" 2017, 64, pp. 222-229.

Yada A., Tolvanen, A., Malinen O., Imai-Matsumura K., Shimada H., Koike R., Savolainen, H., Teachers' self-efficacy and the sources of efficacy: A cross-cultural investigation in Japan and Finland, "Teacher and Teacher Education" 2019, 81, pp. 13- 24.

Zee M., Koomen Y.M.H., Teacher Self-Efficacy and Its Effects on Classroom Processes, Student Academic Adjustment, and Teacher Well-Being: A Synthesis of 40 Years of Research, "Review of Educational Research" 2016, 86, pp. 981-1015. 